\title{
Water Quality Assessment of the Godavari River
}

\author{
Ajay D. Chavan, M.P. Sharma and Renu Bhargava
}

Abstract: The Godavari River is a second largest river in India originating from Trimbakeswar, Nasik, Maharashtra, India. It flows through the states of Madhya Pradesh, Karnataka, Orissa and Andhra Pradesh. The river, passing through Nasik City, is $82 \%$ polluted by domestic pollution and $18 \%$ by industries. The study covers about $65 \mathrm{~km}$ of the river starting from Kushawart Trimbakeswar to Saikheda Village, from where it enters the city. Ten locations were selected for collection of water samples from the river and the samples were analyzed for water quality parameters in the Environmental Laboratory of the Maharashtra Pollution Control Board (MPCB), Nasik. These data as well as data from the Central Pollution Control Board (CPCB) were used to compute the National Sanitation Foundation Water Quality Index (NSFWQI), mostly applicable in the USA and India. The results of NSFWQI of Godavari River indicates its water quality as 'bad' (26-50) or 'medium' (5170) over the study stretch. The NSFWQI of December 2007 and February 2008 indicate an improvement in water quality at all locations over earlier data from 2002-07. Based upon the results, the existing conservation measures have been reviewed and additional measures are suggested. The study concludes that maj or stressor is sewage pollution.

Key words: Water quality parameters, water quality assessment, water quality management, conservation measures

\section{Introduction}

Tresh water is a scarce natural resource today, as $97 \%$ of 1 the surface water is saline water of the oceans while $2 \%$ is locked up in ice-caps and glaciers and the remaining $1 \%$ is expensive to be exploited from the ground. Thus, effectively 0.2 million $\mathrm{km}^{3}$ of water available in rivers, lakes, wetlands, soil moisture, shallow ground water and reservoirs can be used to meet the demands of plants, animals and human beings. Out of 4,000 billion $\mathrm{m}^{3}$ annual rainfall of India, 1,869 billion $\mathrm{m}^{3}$ is lost in natural run-off in streams and rivers, 432 billion $\mathrm{m}^{3}$ goes for recharging the ground water and only 690 billion $\mathrm{m}^{3}$ of the surface water is available for various use. Almost 200 million people in India do not have access to safe and clean drinking water and $90 \%$ of the country's water resources are polluted (Eaton et al 1995). As per an estimate, about 3,035 MLD of water supply during 2003$04, \quad 80 \% \quad(2,428$ MLD) is available as waste water and only $3.67 \%$ (81 MLD) has been treated and $\quad 96.3 \% \quad(2,239$ MLD) as untreated waste water is being discharged to our rivers, streams and lakes, making them highly polluted.

The present study deals with the water quality assessment of $65 \mathrm{~km}$ stretch of Godavari River from Kushawart to Saikheda village in Nasik District in the Indian state of Maharashtra. Attempts were made to identify point and non-point sources of pollution, collect data from CPCB and the study stretch, compute NSFWQI (National Sanitation Foundation Water Quality Index), define the status of water quality, and review existing and suggest additional conservation measures. The study stretch is sacred and attracts pilgrims in large numbers. As a result, the river has become the dustbin for eventual disposal of all sorts of pollutants (waste water, debris, etc.) generated on account of pilgrimage activities, as well as due to rapid

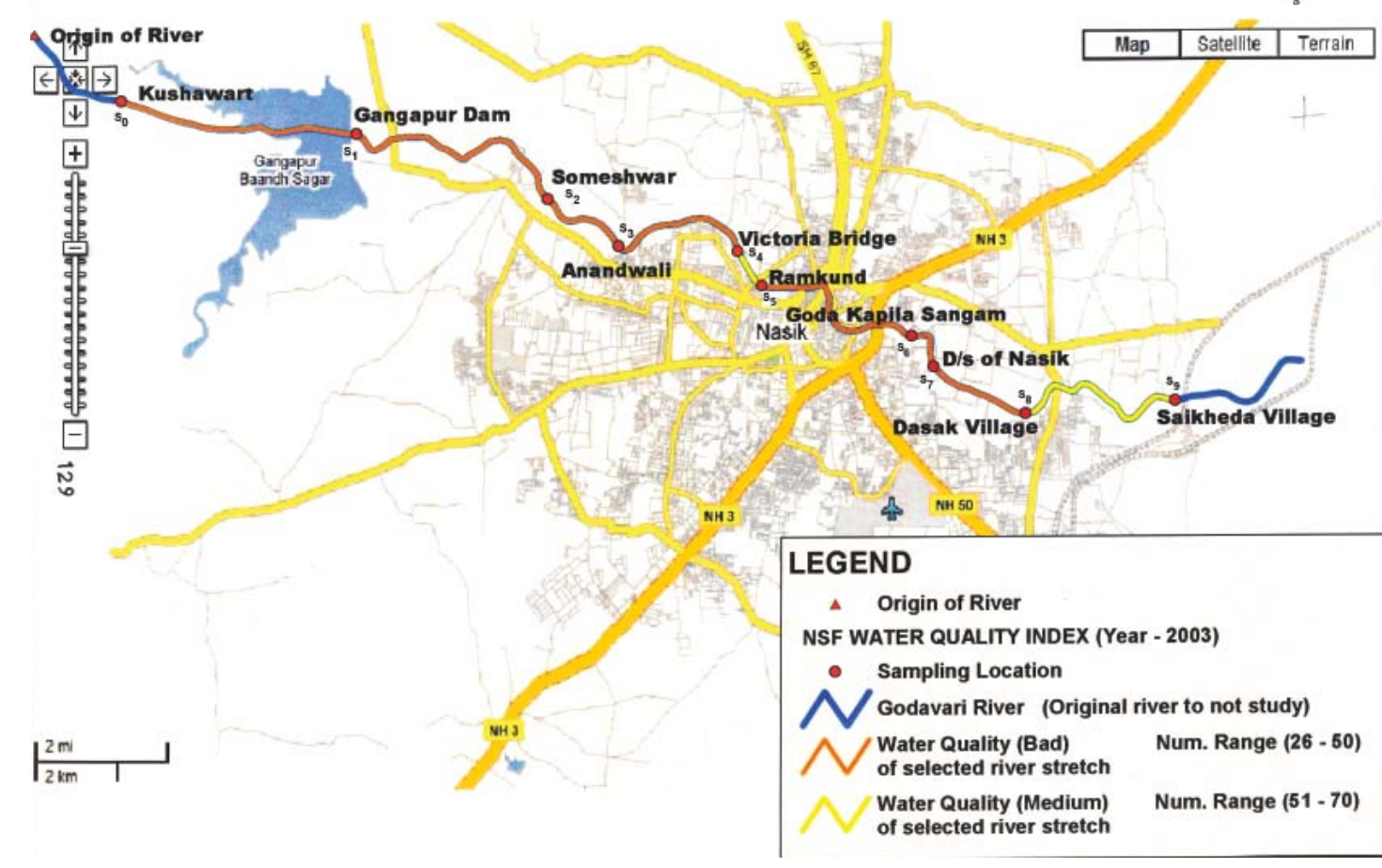

Fig 1. Godavari River Map Showing Sampling Location 
and unplanned growth of human settlements along both sides of the river banks, inadequate sewage disposal and treatment facilitates, lack of bathing ghats, dhobighats (place for washing clothes), etc.

Duringreligiousriversidefestival of Kumbh Mela of 200304, a 78 MLD Sewage Treatment Plant (STP) at Tapowan, Nasik, a 7.5 MLD STP at Dasak Village, and a 12 MLD STP at Takali Village, Solid Waste Treatment Plant and bio- medical waste treatment were commissioned as part of conservation measures for the conservation of Godavari River in the study stretch. As of now, the existing conservation facilities have proved to be inadequate resulting in further pollution of the river. This necessitates the assessment of water quality of the river in the study stretch and suggest management strategies for improving the health of river. Different types of large and medium scale industries apart from small scale units as well as city urban areas are discharging huge untreated industrial effluents and sewage into the river as the major organic pollution as one single reason for river pollution.

\section{Literature Survey}

A literature survey reveals that physico-chemical characteristics of various rivers have been studied by many authors: Chakraborty et al (1959), Rai, (1974), Charu et al 2006, Kallol and Mahapatra (2005) and Das (2005) have measured the physico chemical parameters and assessed the water quality status to the rivers. A comparative study of DO, BOD and COD of Godavari River at Nanded and Rajahmundry has been carried out by Khan, Srinivasarao, Murthy et al (2008) who found that the river was more polluted at Nanded than at Rajahmundry.

\section{About River Godavari and the Study Area}

The River Godavari is the second largest river in the Indian Union. Starting from a trickle from the lips of a cow at Triambak, the width of the river grows till it is nearly 6.5 $\mathrm{km}$ wide at Dowlaiswaram. It is always spoken of as the Southern Ganga and Vriddha Ganga. At Papikonda, it is narrow as 200-300 $\mathrm{m}$ for about $3 \mathrm{~km}$. The Godavari rises in the Western Ghats at Triambak near Nasik, about $113 \mathrm{~km}$ northeast of Bombay and only $80 \mathrm{~km}$ from the Arabian Sea. After descending the Western Ghats, it takes a south easterly course across the southern part of Indian peninsula and flows through 1,230 km and falls into the Bay of Bengal about 80 $\mathrm{km}$ east of Rajahmundry. The total catchment area drained by the river is $312,812 \mathrm{~km}^{2}$, or nearly one tenth of India. The catchment in Maharashtra is about 152,199 $\mathrm{km}^{2}$. The average annual flow ( $50 \%$ dependable flow) of the Godavari basin has been estimated as $110.5 \mathrm{~km}^{3}$, whereas the utilizable flow (75\% dependable flow) is about $76.3 \mathrm{~km}^{3}$. The present utilization is only about $39 \mathrm{~km}^{3}$, which is hardly $50 \%$ (Carg 1999). The annual rainfalls are moderate, from $700 \mathrm{~mm}$ at Nasik to $1,000 \mathrm{~mm}$ at Nizamabad.

The Godavari River passes through the industrially developed Maharashtran city of Nasik. Rapid industrial development is taking place due to the establishment of the industrial areas like Satpur and Ambad MIDC, with the establishment of mainly large and medium scale industries like Motor Industries Company Limited (MCO), Mahindra and Mahindra, VIP Industries, Ceat Limited, Carbon Corporation Limited, ABB Limited, BCL Forging Limited, Glaxo Limited, Siemens, Garware Polyester Ltd, Gabriel, and so on. In addition, 125 large and 350 medium scale units and about 2,500 small scale units are also presently working in the industrial estate and are located at upper part of the city and on the banks of the river. This industrial development has resulted in the massive growth of some other industries like laundry, hotels, restaurants, pathological laboratories, nursing homes, etc. The river water is presently being used for domestic purposes such as drinking, bathing, cleaning, cooling and other, and untreated sewage and industrial effluents together with solid wastes are finding way directly into the river.

\section{Experimental}

In the present study, 10 sampling locations were selected along the Godavari River as given in Table 1 and Figure 1. Only during two months (December 2007 and February 2008) primary data were collected, while the other data from 2002-07 was taken from the records of the Central Pollution Control Board (CPCB) and the Maharashtra Pollution Control Board (MPCB) websites.

Samples were analyzed for SS, TDS, BOD, COD, pH, total hardness, calcium hardness, total alkalinity, chlorides, sodium/potassium, sulphate, phosphate, nitrate, fecal coliform, and electrical conductivity, asper standard methods of analysis (Das 2005). The results of analysis of the samples for December 2007 and February 2008 are given on Tables 2 and 3 , respectively.

All the data have been converted to NSFWQI scores, which gives an idea about the status of water quality at given location at the specified time and help the policy and decision makers at the government and public sector levels to plan for conservation of the river. The numerical scores with water quality descriptions are given on Table 4. A comparison of NSFWQI at the three locations for theyears 2002-08 is given on Table 5, based on data from the CPCB and MPCB.

\section{Results and Discussion}

The results of Tables 2 and 3 as shown in Figure 2 indicate that in December 2007 and February 2008 the water quality

\section{Fig. 2 NSF WQI of Godavari River}

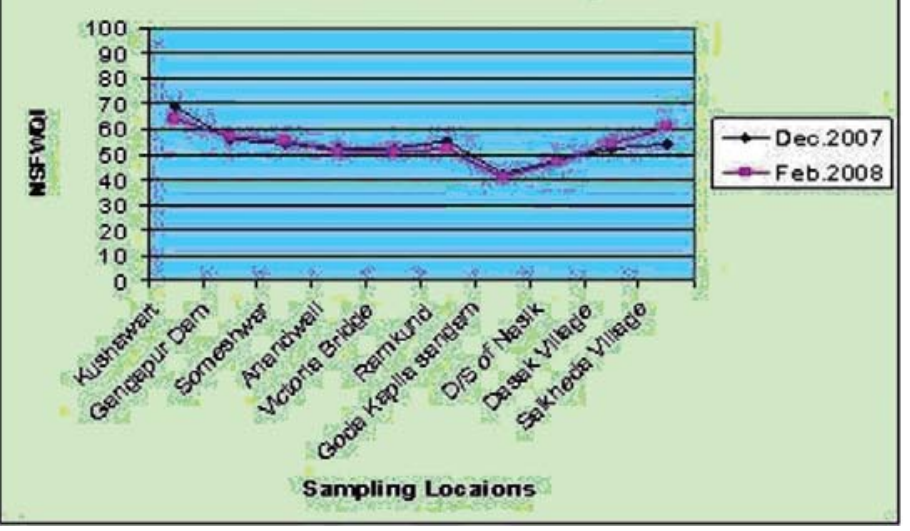


at location $\mathrm{S}_{6}$ and $\mathrm{S}_{7}$ was bad, while the water quality at other locations was medium, thereby indicating that there is not much change in the river water quality at all the locations during this period. As such, the water quality lies between medium to bad due to heavy pollutational load, as indicated above.

The results of Table 5 show that prior to December 2007, the water quality at locations $S_{1}$ and $\mathrm{S}_{5}$ was bad, but it has improved tomedium rangein December 07 and remained so up to February 2008 due to the reasons that some conservation measures likeinstallation of STPs, Effluent Treatment Plant (ETPs), solid waste management, biomedical waste management facilities started to function and treated water started to be discharged into the river. The observation of no further improvement in the quality beyond December 2007 and February 2008 can be attributed to the fact that the capacity of existing facilities have either became inadequate or these are not properly functioning and managed. The water quality at location $\mathrm{S}_{7}$ has not recorded any improvement due to the discharge of untreated waste water in the downstream. As indicated above, the existing conservation facilities in the study area include STP of 78, 7.5 and 22 MLD capacity at
Table 1. Sampling Locations in the Study Stretch of the Godavari River

\begin{tabular}{|c|c|c|c|c|c|c|c|c|c|c|c|c|}
\hline & Category & \multicolumn{2}{|c|}{$\begin{array}{c}\text { Sampling } \\
\text { station }\end{array}$} & Location & $\begin{array}{l}\text { Distance } \\
\text { from the } \\
\text { origin }\end{array}$ & \multicolumn{7}{|c|}{ Remarks } \\
\hline 1 & River Point & \multicolumn{2}{|c|}{$\mathrm{S}_{0}$} & Kushawart & $10 \mathrm{~km}$ & \multicolumn{7}{|c|}{ Origin of River with no anthropogenic impacts } \\
\hline 2 & River Point & \multicolumn{2}{|c|}{$5_{1}$} & $\begin{array}{l}\text { Gangapur } \\
\text { Dam, Nasik }\end{array}$ & 28 & \multicolumn{7}{|c|}{$\begin{array}{l}\text { - Monitored by CPCB. } \\
\text { - Dam is source of drinking water }\end{array}$} \\
\hline 3 & River Point & \multicolumn{2}{|c|}{$\mathrm{S}_{2}$} & Someswar & 34 & \multicolumn{7}{|c|}{ Bathing, washing activities and puja material thrown } \\
\hline 4 & River Point & \multicolumn{2}{|c|}{$\mathrm{S}_{3}$} & Anandwali & 39 & \multicolumn{7}{|c|}{ Sewage from restaurants, hotels etc. to the river. } \\
\hline 5 & River Point & \multicolumn{2}{|c|}{$\mathrm{S}_{4}$} & $\begin{array}{l}\text { Victoria } \\
\text { Bridge }\end{array}$ & 42 & \multicolumn{7}{|c|}{ Sewage is discharged into the river. } \\
\hline 6 & River Point & \multicolumn{2}{|c|}{$\mathrm{S}_{5}$} & Ramkund & 43 & \multicolumn{7}{|c|}{ Mass bathing activities } \\
\hline 7 & River Point & \multicolumn{2}{|c|}{$\mathrm{S}_{6}$} & $\begin{array}{c}\text { Goda Kapila } \\
\text { Sangam }\end{array}$ & 45 & \multicolumn{7}{|c|}{$\begin{array}{l}\text { - Kapila river meets } \\
\text { - Sewage/ other waste water added. }\end{array}$} \\
\hline 8 & River Point & 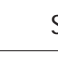 & 7 & $\begin{array}{l}\text { Tapowan, } \\
\text { D/s Nasik }\end{array}$ & 46 & Trea & was & ater & 78 & D STP & ets $t$ & iver \\
\hline 9 & River Point & & 8 & $\begin{array}{l}\text { Dasak } \\
\text { Village }\end{array}$ & 52 & $\begin{array}{l}\text { Rem } \\
\text { wat } \\
\text { was }\end{array}$ & $\begin{array}{l}\mathrm{ns} / \mathrm{a} \\
\text { from } \\
\text { gs a }\end{array}$ & $\begin{array}{l}\text { Sof hi } \\
\text { ttlem } \\
\text { d }\end{array}$ & $\begin{array}{l}n \text { dea } \\
\text { i oil a }\end{array}$ & $\begin{array}{l}\text { bodies } \\
\text { d greas }\end{array}$ & from & $\begin{array}{l}\text { aste } \\
\text { icle }\end{array}$ \\
\hline 10 & River Point & S & $b_{9}$ & $\begin{array}{l}\text { Saikheda } \\
\text { Village }\end{array}$ & 75 & $\begin{array}{ll}- & R \\
W \\
W \\
\text { - } \\
\text { H } \\
\text { d }\end{array}$ & $\begin{array}{l}\text { nain/ } \\
\text { ter fro } \\
\text { shings } \\
\text { spital } \\
\text { charge }\end{array}$ & $\begin{array}{l}\text { es of } h \\
\text { settlen } \\
\text { Ided } \\
\text { stes an } \\
\text { to the }\end{array}$ & $\begin{array}{l}\text { nan de } \\
\text { nts/ o } \\
\text { over fl } \\
\text { er }\end{array}$ & $\begin{array}{l}\text { d bodies } \\
\text { and gre } \\
\text { from s }\end{array}$ & $\begin{array}{l}\text { sewag } \\
\text { se fron } \\
\text { ptic ta }\end{array}$ & $\begin{array}{l}\text { waste } \\
\text { ehicle } \\
\text { «s is }\end{array}$ \\
\hline & Paramete & & & & & & implin & catio & & & & \\
\hline & 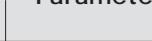 & & SO & S1 & S2 & S3 & S4 & S5 & S6 & S7 & S8 & S9 \\
\hline 1 & $\mathrm{PH}^{\mathrm{H}}$ & & 7.11 & 8.10 & 7.78 & 7.86 & 8.27 & 7.50 & 7.60 & 7.75 & 7.6 & 7.86 \\
\hline 2 & DO & & 1.95 & 6.8 & 7.0 & 5.7 & 4.7 & 5.0 & 4.0 & 4.6 & 4.8 & 3.60 \\
\hline 3 & BOD & & 85 & 5.1 & 5.7 & 8.0 & 8.1 & 10.3 & 11.8 & 15 & 21 & 9 \\
\hline 4 & COD & & 152 & 21 & 24 & 29 & 30 & 40 & 37 & 40 & 36 & 44 \\
\hline 5 & $\begin{array}{l}\text { electrical } \\
\text { conductivit }\end{array}$ & & 379 & 200 & 279 & 154 & 170 & 160 & 160 & 594 & 523 & 270 \\
\hline 6 & TSS & & 16 & 22 & 25 & 35 & 34 & 49 & 46 & 49 & 30 & 52 \\
\hline 7 & TDS & & 210 & 180 & 490 & 335 & 535 & 299 & 155 & 487 & 212 & 215 \\
\hline 8 & chlorides & & 37 & 11 & 18 & 69 & 89 & 100 & 1 & 50 & 41 & 35 \\
\hline 9 & total hardn & & 100 & 78 & 118 & 114 & 135 & 190 & 196 & 198 & 230 & 236 \\
\hline 10 & $\begin{array}{l}\text { calcium } \\
\text { hardness }\end{array}$ & & 120 & 46 & 78 & 70.6 & 81 & 122 & 1 & 40 & 46 & 49 \\
\hline 11 & $\begin{array}{l}\text { magnesium } \\
\text { hardness }\end{array}$ & & 11.67 & 32 & 40 & 43.4 & 54 & 68 & 89 & 17.02 & 27 & 25.3 \\
\hline 12 & sodium & & 18 & 6.0 & 11 & 10 & 17 & 21 & 27 & 28 & 25 & 29 \\
\hline 13 & sulphates & & 29 & 5.16 & 17 & 29 & 24 & 14.6 & 14.5 & 38.2 & 59 & 0.48 \\
\hline 14 & phosphates & & 450 & 0.011 & 0.06 & 0.05 & 0.07 & 0.04 & 0.07 & 2.94 & 0.54 & 0.50 \\
\hline 15 & nitrate & & 0.478 & 0.23 & 0.27 & 1.39 & 1.81 & 0.8 & 1.12 & 0.021 & 2.89 & 0.03 \\
\hline 16 & NSFWQI & & 69 & 56 & 54 & 52 & 52 & 55 & 42 & 48 & 52 & 54 \\
\hline
\end{tabular}

Table 2: Parameters for Water Quality Assessment of Godavari River (December 2007)

\begin{tabular}{|c|c|c|c|c|c|c|c|c|c|c|c|}
\hline & \multirow{2}{*}{ Parameters } & \multicolumn{9}{|c|}{ Sampling locations } & \multirow[b]{2}{*}{59} \\
\hline & & So & S1 & $\mathrm{S} 2$ & S3 & S4 & S5 & S6 & S7 & S8 & \\
\hline 1 & $\mathrm{P}^{\mathrm{H}}$ & 7.01 & 7.30 & 7.99 & 7.91 & 8.30 & 7.20 & 7.10 & 7.69 & 7.68 & 7.78 \\
\hline 2 & DO & 1.9 & 7.5 & 7.4 & 5.8 & 4.7 & 4.8 & 3.1 & 1.6 & 4.17 & 3.40 \\
\hline 3 & BOD & 24 & 4.8 & 5.9 & 7.3 & 7.60 & 9.8 & 10.3 & 36 & 24 & 12 \\
\hline 4 & COD & 40 & 28 & 19 & 21 & 33 & 24 & 33 & 84 & 40 & 32 \\
\hline 5 & electrical conductivity & 426.5 & 189 & 248 & 296 & 378 & 370 & 620 & 599.5 & - & 240 \\
\hline 6 & total suspended solids & 27 & 45 & 51 & 36 & 26 & 41 & 51 & 40 & 35 & 52 \\
\hline 7 & total dissolved solids & 340 & 165 & 149 & 139 & 221 & 156 & 597 & 212 & 166 & 215 \\
\hline 8 & chlorides & 53 & 17 & 19 & 37 & 62 & 93 & 129 & 85 & 37.5 & 45 \\
\hline 9 & total hardness & 140 & 126 & 126 & 127 & 191 & 96 & 214 & - & 260 & 256 \\
\hline 10 & calcium hardness & 64 & 92 & 80 & 81.2 & 122 & 66 & 148 & - & 56 & 99 \\
\hline 11 & magnesium hardness & 2.44 & 34 & 46 & 45.8 & 69 & 30 & 66 & - & 3.76 & 29.3 \\
\hline 12 & sodium & 19 & 25 & 5.0 & 8.5 & 9.5 & 16.5 & 35 & - & - & 39 \\
\hline 13 & sulphates & 18 & 3.28 & 27 & 23 & 25 & 15.4 & 16.6 & - & 75 & 68 \\
\hline 14 & phosphates & 0.358 & 0.015 & 0.5 & 0.14 & 0.21 & 0. & 0.04 & - & 0.52 & 0.90 \\
\hline 15 & nitrate & 0.833 & 0.15 & 0.90 & 1.93 & 2.23 & 0.97 & 0.99 & - & 3.76 & 0.13 \\
\hline 16 & NSFWQI & 64 & 57 & 55 & 51 & 51 & 52 & 41 & 47 & 54 & 61 \\
\hline
\end{tabular}

Table 3. Parameters for Water Quality Assessment of Godavari River (February 2008) 


\begin{tabular}{|l|l|l|l|}
\hline & Water quality & $\begin{array}{c}\text { NSFWQI } \\
\text { score }\end{array}$ & Color \\
\hline 1 & Very Bad & $0-25$ & Red \\
\hline 2 & Bad & $26-50$ & Orange \\
\hline 3 & Medium & $51-70$ & Yellow \\
\hline 4 & Good & $71-90$ & Green \\
\hline 5 & Excellent & $91-100$ & Blue \\
\hline
\end{tabular}

Table 4. NSFWQI Scores and WQ descriptions

\begin{tabular}{|c|c|c|c|c|c|c|c|}
\hline & \multicolumn{7}{|c|}{ NSFWQI } \\
\hline & 2002 & 2003 & 2004 & 2005 & 2006 & 2007 & 2008 \\
\hline $\begin{array}{l}\text { Gangapur Dam, Nasik } \\
\left(\mathrm{S}_{1}\right)\end{array}$ & $\begin{array}{c}36 \\
\text { bad }\end{array}$ & $\begin{array}{c}38 \\
\text { bad }\end{array}$ & $\begin{array}{l}40 \\
\text { bad }\end{array}$ & $\begin{array}{c}42 \\
\text { bad }\end{array}$ & $\begin{array}{c}49 \\
\mathrm{bad} / \text { medium }\end{array}$ & $\begin{array}{c}56 \\
\text { medium }\end{array}$ & $\begin{array}{c}57 \\
\text { medium }\end{array}$ \\
\hline $\begin{array}{l}\text { Godavari River } \\
\text { Ramkund, Nasik }\left(\mathrm{S}_{5}\right)\end{array}$ & $\begin{array}{c}35 \\
\text { bad }\end{array}$ & $\begin{array}{c}34 \\
\text { bad }\end{array}$ & $\begin{array}{l}40 \\
\text { bad }\end{array}$ & $\begin{array}{c}40 \\
\text { bad }\end{array}$ & $\begin{array}{c}44 \\
\text { bad }\end{array}$ & $\begin{array}{c}55 \\
\text { medium }\end{array}$ & $\begin{array}{c}52 \\
\text { medium }\end{array}$ \\
\hline $\begin{array}{l}\text { Godavari River d/ s of } \\
\text { Nasik }\left(\mathrm{S}_{7}\right)\end{array}$ & $\begin{array}{c}34 \\
\text { bad }\end{array}$ & $\begin{array}{c}35 \\
\text { bad }\end{array}$ & $\begin{array}{l}40 \\
\text { bad }\end{array}$ & $\begin{array}{c}41 \\
\text { bad }\end{array}$ & $\begin{array}{l}45 \\
\text { bad }\end{array}$ & $\begin{array}{c}48 \\
\text { bad }\end{array}$ & $\begin{array}{c}47 \\
\text { bad }\end{array}$ \\
\hline
\end{tabular}

Table 5. Comparison of NSFWQI in Different Years at Three Locations
Tapowan, Dasak and Takali respectively, as well as the solid wastetreatment plant and bio-medical wastetreatment plant, etc., that have become inadequate in view of the expansion of the industrial base and rapid growth of the population in the catchment of the study area. The presence of fecal coliform in the river is attributed to the discharge of sewage into the river near its banks.

In view of the above, it is proposed to review and add the additional STPs, ETPs, Municipal Solid Waste (MSW) management, hospital/ biomedical facilities in the area along with low cost sanitation, electric crematoria, construction of bathing ghats/river front developments, afforestation and landscaping, rain water harvesting, organization of short term awareness/training programs for the local people, in order to revolutionize the concept and benefits of a clean environment.

\section{Conclusions}

The water quality assessment of a $65 \mathrm{~km}$ stretch of Godavari River in Nasik District from Kushawart to Saikheda village in Maharashtra State indicates that the river is heavily polluted due to 125 large and 350 medium scale units and about 2,500 small scale units, in addition to massive growth of some other industries like laundry, hotels, restaurants, pathological laboratories, nursing homes, etc., which are discharging into the river. The National Sanitation Foundation Water Quality Index (NSFWQI), computed from December 2007 and February 2008, as well as from 2002-07 (from CPCB and MPCB) indicate that the study stretch had bad water quality up to 2006, but that improved to medium due to conservation facilities implemented in 2005. The water quality has not improved beyond medium range up to February 2008, perhaps due either to the fact that current facilities have become inadequate or are not properly functioning. It is therefore suggested that in the light of present development in the study stretch, there is need to reassess the required facilities and to take effective steps to put them into full operation to achieve the targets.

Ajay D. Chavan, is a civil engineer, admitted to the M. Tech program on 'Conservation of Rivers and Lakes, AHEC, Indian Institute of Technology (IIT), Roorkee, India as a sponsored candidate from Maharashtra Pollution Control Board, Nasik. He completed his dissertation on the topic Water quality management of Godavari River in Nasik city' in 2008-09.

M.P. Sharma, $\mathrm{PhD}$, has been working as Associate Professor at AHEC, since the last 25 years. His area of research is renewable energy with special reference to modeling of IRES, hybrid energy systems, modeling of induction generators, environmental impact assessment of renewable energy projects, energy conservation, conservation of environment, conservation of water bodies, water quality assessment, and biodiesel production and utilization.

Corresponding address:

mpshafah@iitr.ernet.in, mahendrapal_sharma@gmail.com.

Prof. Renu Bhargava works at Civil Engineering Department, IIT, India in the area of waste water treatment technologies, solid waste management, vermi composting etc. Corresponding address: renbhfce@iitr.ernet.in

\section{References}

Bansal, P.C., 2004, Water Management in India, New Delhi: Concept Publishing Company.

Chakrabarty, R.D, P. Ray and S.I. Singh, 1959. 'A quantitative study ot the plankton and physico-chemical conditions of river J amuna at Allahabad', Indian J ournal of Fisheries 6(1):186-203. Charu P., D. Savitaand R. Srivastava, 2006, 'Seasonal variations in physico-chemical characteristics in upper lake of Bhopal,', Asian J ournal of Experimental Sciences 20(2):297-302.

CPCB, Central Pollution Control Board, India. URL: www. cpcb.nic.in/mar95ii.htm.

Das, D.N., 2005, 'Studies on the sources of pollution in Tunia river,' M. Tech. Project, AHEC Indian Institute of Technology, Roorkee, India.

Eaton, A.D., L.S. Clesceri and A.E. Greenberg, eds., 1995, Standard Methods for the Examination of Water and Waste Water, 19th ed., Washington DC: American Public Health Association (APHA).

Garg, Santosh Kumar, 1999, International and InterstateRiver Water Disputes in India, New Delhi: Laxmi Publications.

Kallol, Dey and S.C. Mohapatra, 2005, 'Assessment of water quality parameters of river Brahmani at Rourkela,' Indian J ournal of Pollution Control 21(2):265-70.

Khan, A.M., V. Srinivasarao, Y.L.N. Murthy, et al, 2008, 'Assessment of water quality of Godavari River at Nanded, Maharashtra and Rajamundry, Andhra Pradesh,' J ournal of Chemistry and Environment 12(1):65-68.

MPCB, Maharashtra. India, Maharashtra Pollution Control Board. URL: www.mpcb.mah.nic.in.

Rai, H., 1974, Limnological studies on river Yamuna at Delhi, India, Part-II: Relation between thechemistry \&states of pollution in river Yamuna,' Archives of Hydrobiology 73(3):369-393. 